\title{
Threatened fishes of the world: Percilia irwini (Eigenmann 1927) (Perciliidae)
}

\author{
Evelyn Habit \\ University of Concepcion \\ Mark C. Belk \\ Brigham Young University - Provo, mark_belk@byu.edu
}

Follow this and additional works at: https://scholarsarchive.byu.edu/facpub

Part of the Biology Commons

\section{Original Publication Citation}

Habit, E., and M.C. Belk. 2007. Threatened fishes of the world: Percilia irwini Eigenmann, 1927 (Perciliidae). Environmental Biology of Fishes, 78:213-214.

\section{BYU ScholarsArchive Citation}

Habit, Evelyn and Belk, Mark C., "Threatened fishes of the world: Percilia irwini (Eigenmann 1927) (Perciliidae)" (2007). Faculty Publications. 5461.

https://scholarsarchive.byu.edu/facpub/5461

This Peer-Reviewed Article is brought to you for free and open access by BYU ScholarsArchive. It has been accepted for inclusion in Faculty Publications by an authorized administrator of BYU ScholarsArchive. For more information, please contact ellen_amatangelo@byu.edu. 


\title{
Threatened fishes of the world: Percilia irwini (Eigenmann 1927) (Perciliidae)
}

\author{
Evelyn Habit ${ }^{\mathrm{a}} \&$ Mark C. Belk ${ }^{\mathrm{b}}$ \\ ${ }^{a}$ Aquatic Unit System, Environmental Science Centre Eula-Chile, University of Concepción, Barrio \\ Universitarios/n, Concepción, Chile (e-mail: ehabit@udec.cl) \\ ${ }^{\mathrm{b}}$ Department of Integrative Biology, Brigham Young University, Provo, UT, 84602, USA
}

\author{
Received 22 April $2005 \quad$ Accepted 9 January 2006
}

Common name: Carmelita de Concepción (Spanish). Conservation status: Percilia irwini is considered an endangered species in Chile (Campos et al. 1998), and listed as data deficient according to the World Conservation Union (IUCN 2004). Identification: $P$. irwini is a small percoid, maximum length of $96 \mathrm{~mm}$, and typical total length of $60 \mathrm{~mm}$. It has large ctenoid scales on trunk and posterior part of the dorsum of head; with small cycloid scales on the cheek. Lateral line has 35-39 scales. D: IX, 11-13, the third dorsal spine is the longest, A: III $+9-10$. The dorsal border between the upper jaw and origin of the dorsal fin is convex, with 5-6 branchiostegals; 34-36 vertebrae, and four pyloric ceca. It

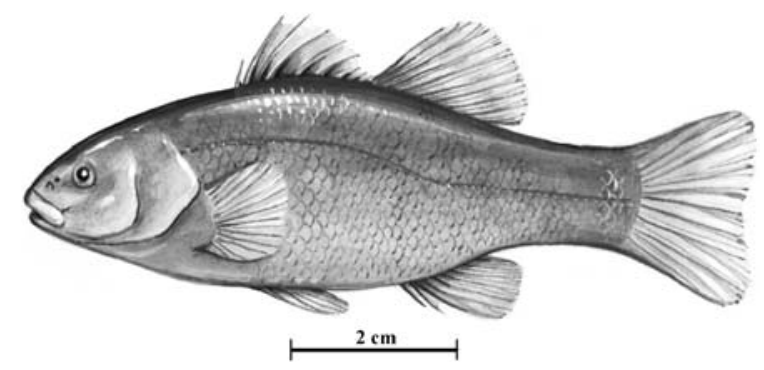
has an enclosed sensory canal in the postemporal and extrascapular bones (Arratia 1982). Sexes are monomorphic. Illustration by Pedro Victoriano. Distribution: P. irwini is endemic to the Biobío and Andalién river basins, of south-central Chile. Abundance: This species exhibit a gradient of abundance from low numbers in rithral/transitional habitats in headwater areas to higher numbers in potamal areas in the middle-lower reaches in rivers. In rithral areas abundances increase somewhat during low flow seasons (January-March). Habitat and ecology: P. irwini is a bentho-pelagic fish inhabiting shallow $(<1 \mathrm{~m})$ and slow $\left(<0.5 \mathrm{~m} \mathrm{~s}^{-1}\right)$ waters of lakes (Laja, Icalma and Galletué) and rivers. They typically occur over boulders or a mixed substrate of boulders, gravel and sand patches. This species feeds mainly on chironomid larvae and other aquatic insects (mayflies, caddisflies) and small mollusks (E. Habit, unpublished). It attains a maximum age of 4 years with most rapid growth during the first year (Habit \& Belk, unpublished). Reproduction: Males and females exhibit highest gonado-somatic index from late winter through spring (August-November; Habit \& Belk, unpublished). Males are larger than females at the same age, suggesting a possible active role of males in some degree of parental care. During the breeding season fins and body of both sexes exhibit bright orange coloration. No other information is available about the reproductive biology of this species. Threats: $P$. irwini is threatened by pollution due to industrial and domestic effluents. In areas locally impacted by effluents $P$. irwini is replaced by the tolerant, invasive species, Gambusia holbrooki. Habitat loss due to hydropower plants in the Biobío basin is another important threat (Habit et al. 2002). Conservation actions: Conservation actions thus far have included population assessments at selected locations in both the Andalién and Biobío basins, and a translocation program in the Laja River to augment populations after a significant decline caused by the construction and operation of a new diversion hydropower facility (Habit et al. 2002). More information about habitat use, trophic niche, reproduction, behavior, and interaction with introduced species ( $G$. holbrooki, and salmonids) are needed to guide future conservation and management actions. Remarks: Perciliidae is a monotypic family, endemic to the Chilean Province (Dyer 2000). The sister species of $P$. irwini is $P$. gillissi Girard, 1855, which has a broader distribution from Aconcagua River in the north to Llanquihue Lake in the south. $P$. gillissi has been described in sympatry with $P$. irwini in the Andalién River Basin (Ruiz 1993). Like P. irwini, $P$. gillissi is considered an endangered species, but only in the northern part of its range (from Aconcagua River to Rapel River). The World Conservation Union listed $P$. gillissi as data deficient (IUCN 2004).

Arratia, G. 1982. A review of freshwater percoids from South America (Pisces, Osteichthyes, Perciformes, Percichthyidae, and Perciliidae). Abh. Senckenberg Naturforsch. Ges. 540: 1-52.

Campos, H., G. Dazarola, B. Dyer, L. Fuentes, J. Gavilán, L. Huaquín, G. Martínez, R. Meléndez, G. Pequeño, F. Ponce, V. Ruiz, W. Siefeld, D. Soto, R. Vega \& I. Vila. 1998. Categorías de conservación de peces nativos de agues continentales de Chile. Boletín del Museo Nacional de Historia Natural 47: 101-122. 
Dyer, B. 2000. Systematic review and biogeography of the freshwater fishes of Chile. Estudios Oceanológicos (Chile) 19: 77-98. Habit, E., P. Victoriano \& O. Parra. 2002. Translocación de peces nativos en la cuenca del río Laja (Región del Biobío, Chile). Gayana 66: 181-190.

Ruiz, V. 1993. Ictiofauna del río Andalién (Concepción, Chile). Gayana Zool. 57(2):109-278.

IUCN. 2004. Red List of Threatened Species. www.redlist.org. Downloaded on 16 April 2005. 